JWAM

9,2

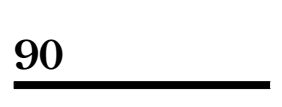

\title{
Editorial
}

\section{Exploring the impact of reflective and work applied approaches}

Welcome to Volume 9, Issue 2, of the Journal of Work Applied Management (JWAM), a Special Issue dedicated to exploring the impact of reflective and work applied approaches. The impact agenda is now a global phenomenon with great expectations for "transformational" impacts in the wider world (Gravem et al, 2017). Paradoxically, such demands can hinder discovery through the avoidance unpredictable outcomes (Gravem et al, 2017), and problematically, there is an over reliance on very narrow conceptualisations of impact, oftentimes adopting the metrics used by research councils or governments to allocate research monies. Such metrics are fiercely debated, partly because of a disconnect with practice, and their significance in creating and shaping industries whose primary purpose it is to administer and optimise the administration of research assessment activity (Wall, 2016a, b).

Pluralistic alternative measures have been proposed (see Aguinis et al, 2014), which have integrated metrics such as social media citations, but even these may be conceptualised as limited and potentially increase the complexity and overhead of making sense of impact in workplace contexts. Similarly, in the context of work applied learning and management, discussion of impact can be criticised for being too localised to generate wider societal benefit (Sun and Kang, 2015; Fleming and Haigh, 2017; Wall, 2017). Therefore, the aim of this Special Issue was to stimulate debate and practices in relation to impact in the context of work applied learning and management, in terms of:

- alternative conceptualisations of impact and research impact in the context of reflective practice and/or workplace or work-based learning;

- theoretically informed reformulations of impact in the context of reflective practice and/or workplace or work-based learning;

- research or commentaries into how impact might shape reflective practices or workplace or work-based learning approaches; and

- contradictions, dilemmas, tensions, or double binds in managing or realising impact in the context of reflective practices or workplace or work-based learning approaches (Wall and Perrin, 2015; Wall, 2016c).

As you will soon discover, the Special Issue attracted a wide range of perspectives, practices, and provocations in line with a more pluralistic notion of impact, and the areas of debate above. In the first paper, Wall, Bellamy, Evans and Hopkins (2017) provide a contemporary synthesis and review of the impact agenda in relation to work applied management and change approaches. In their paper entitled "Revisiting impact in the context of workplace research: a review and possible directions", they draw on a diverse range of data to provide a more nuanced commentary on three key dimensions of, and pathways to, impact: the potentiality of the interactive, discursive nature of all research activity in shaping impact, the potential role of presence (and perhaps non-action) in shaping and delivering

\footnotetext{
(c) Tony Wall. Published in Journal of Work-Applied Management. Published by Emerald Publishing Limited. This article is published under the Creative Commons Attribution (CC BY 4.0) licence. Anyone may reproduce, distribute, translate and create derivative works of this article (for both commercial \& non-commercial purposes), subject to full attribution to the original publication and authors. The full terms of this licence may be seen at http://creativecommons.org/licences/by/4.0/legalcode

The writing of this paper was supported by a University of Chester QR Grant.
}

Journal of Work-Applied Management Vol. 9 No. 2, 2017 pp. $90-94$ Emerald Publishing Limited 2205-2062 DOI 10.1108/JWAM-10-2017-0028 
impact, and the narrative nature of time means there is instability in making sense of impact over time. These insights highlight the omnipresence and omnipotent potential of research in organisational settings, especially in the context of work applied management and change approaches. In turn, such insights challenge us in such fundamental ways that we need to re-think how we position ourselves and our research in workplaces, in terms of responsibility, sustainability, and ethics (Wall, Hindley, Hunt, Peach, Preston, Hartley and Fairbank, 2017). There are a variety of practical implications of such insights, including how we train practitioner researchers.

In the next paper, Scott (2017) responds to critiques about the limited impact of critical reflection in workplaces by offering the counter-metaphor of "the ignorant manager: conceptualising impact with Rancière". Underpinned by the philosophical thought of French Philosopher Jacques Rancière, Scott raises the possibilities that can be afforded when managers take a stance of ignorance. Specifically, she argues that in taking such as stance, managers can operate outside of their own constraining repertoire of experience and expertise, and thereby generate unpredictable but deeper forms of learning and broader impacts. As such, this provides a space and platform for greater equality and agency for practitioner researchers in the workplace. Methodologically, Scott engages a "methodology of the heart" which aims to connect and resonate with the research audience to affect change (Sparkes, 2007; Wall, 2016a, b, c).

This stance of "ignorance", or operating outside of pre-established and structuring repertoires of experience and expertise, is raised again in the next paper. Here, Robins (2017) explores "Impact through coaching: does the use of models limit connectedness in coaching?" Robins draws on the kind of practical wisdom generated through years of experience and reflection to become aware of the structuring (and possibly inhibiting) role of models in coaching, a professional practice that has gained immense momentum and popularity in work applied management and change settings. Specifically, she argues that models can be unhelpfully disruptive to the sorts of connectedness that is so centrally important in efficacious coaching and change practice. She refers to the role and appropriateness of "open space" methodological approaches, which resonate with the positive and productive states for change to which Scott referred, and which foreground equality in change efforts (Wall, Tran and Soejatminah, 2017).

In the fourth paper, Wall, Russell and Moore (2017) then bring us "Positive emotion in workplace impact: the case of a work-based learning project utilising appreciative inquiry", and explicate the role of positive emotion in pathways to workplace impacts. They draw on an example of a work-based learning project utilising the highly efficacious (yet still controversial) methodological perspective of appreciative inquiry. Not only do they demonstrate that appreciative inquiry can be flexibly adapted to difficult organisational settings, but that it can also be effectively used in time-bound work-based learning projects. Their paper amplifies the necessity and possibility of attending to the well-being of the people involved in change or transformation projects in the workplace, an area that it is increasingly important in workplaces and applied methodologies (Wall, 2017).

Poole (2017) then provides a radical re-think and re-visioning of the impact debate in his "re/searching for 'Impact'". Here, Poole prompts us to re-gain and re-vitalise our creative capacities as human beings, and in doing so, amplifies a way of connecting research as a form of searching - or curiosity - which is so necessary to live a life full of energetic curiosity. To explicate and articulate his argument, Poole draws on arts-based practices which aid the practitioner researcher in connecting to wider sensations or ways of knowing, where impacts are the things "which come out" rather than known and prescribed at the start of research. This responds to the concerns of Gravem et al. (2017), where being prescriptive to be "transformational" can have the opposite effects in practice. Poole exemplifies such exploratory processes through three creative and original practices which 
JWAM

9,2

speak to the ambition of re/searching: Phrónetic Vlogging, Ekphrasis, and Perambulography. In the spirit of offering additional pathways to further knowledge, and a first for the JWAM, Poole provides QR codes which embed links to (web) sites with additional media. We invite you to follow the links to find out more!

In the sixth paper, the theme of creative practices to engender impact in workplaces is further developed and elaborated. Drawing on innovation practices from Finland, Pässilä $e t$ al. (2017) present the paper entitled "Beyond text: the co-creation of dramatised character and iStory". The paper, drawing on a major international research and innovation dissemination project, focuses on the use of drama- and story-based practice to facilitate deep insight and "Eureka" moments. Here, operating in "as if" states of being or "as if" storylines seem to facilitate different trajectories of action, and therefore open up alternative pathways to influence and impact in the workplace (Wall and Perrin, 2015).

The significant potential of story and drama process is also referred to in Rossetti and Wall's (2017) paper on "The impact of story: measuring the impact of story for organisational change", the seventh paper of this Special Issue. In one sense, this paper provides additional contemporary evidence of how story and storytelling activates the positive and productive psychological states that are so conducive to organisational change and personal transition. In another sense, it also provides tools and techniques to be able to measure and monitor such impacts in real organisational settings, as part of work applied management and change contexts. The most significant change technique is a particularly practical approach which can be deployed as a foundational tool, flexed to the specific needs of multiple stakeholder groups. It also connects to the international work of Lapidus International, the words for well-being organisation (www.lapidus.org.uk), which recognises and promotes work of this nature. This paper stands as a landmark as it is one of the first to be published in the context of work-based learning or work applied management.

In the final paper, Rowe et al. (2017) present the paper "The challenges of managing degree apprentices in the workplace: a manager's perspective”. This paper captures a time sensitive, early snapshot of attempts to increase the number of apprentices in the UK, and adopts the unique perspective of managers involved in this national initiative. As the apprenticeship model in the UK adopts work-based learning and work applied management approaches, it highlights some of the challenges of realising the impacts of such models when configured in such ways (Rowe et al., 2016). Interestingly, whereas the other papers predominantly examined the pedagogical strategies and structures to deliver impact, this paper amplifies the importance of other human resource factors including employer-led recruitment processes, the management of expectations of work-based learning and work applied methodologies, student retention strategies, and effective workplace mentoring and support strategies.

As 2017 comes to a close, we may utilise the ideas in this Special Issue to reflect on some of our own insights from 2017 (and before) to guide us into 2018 (and beyond). Although not explicitly a theme of the call for papers for Special Issue, an overarching theme which is present in each of the papers relates to creating spaces for new ideas and practices to emerge: the spaces in and through conversations (Wall, Bellamy, Evans and Hopkins, 2017); spaces for equality through ignorance (Scott, 2017); open spaces for people to connect through coaching and to travel to new destinations together (Robins, 2017); open and generative spaces through positive emotion (Wall, Russell and Moore, 2017); spaces for curiosity through (re)searching (Poole, 2017); opening spaces through drama and story (Pässilä et al., 2017); opening spaces for improvement through story (Rossetti and Wall, 2017); and the spaces that need careful set up and management with and amongst stakeholders when engaging in work-based learning and work applied management methodologies (Rowe et al., 2017). To this end, 
some questions prompted by this Special Issue, and which might stimulate our ongoing inquiry, might include:

- What research spaces are we curating to enable conversations and creativity?

- What models are we adopting? How are they constraining? How might they be opening up spaces?

- What research practices are we adopting to stimulate curiosity in research practices?

- Where might we inject a state of ignorance, to enable wider and deeper learning around us?

- What research practices might we adopt to stimulate positive emotion states to achieve even deeper and broader pathways to impact?

- What might we need to do to carefully set up and manage the expectations of those in the spaces we co-create?

Tony Wall

\section{References}

Aguinis, H., Shapiro, D.L. and Antonacopoulou, E.P. (2014), "Scholarly impact: a pluralist conceptualization”, Academy of Management Learning \& Education, Vol. 13 No. 4, pp. 623-639.

Fleming, J. and Haigh, N.J. (2017), "Examining and challenging the intentions of work-integrated learning", Higher Education, Skills and Work-Based Learning, Vol. 7 No. 2, pp. 198-210, available at: https://doi.org/10.1108/HESWBL-01-2017-0003

Gravem, S.A., Bachhuber, S.M., Fulton-Bennett, H.K., Randell, Z.H., Rickborn, A.J., Sullivan, J.M. and Menge, B.A. (2017), "Transformative research is not easily predicted", Trends in Ecology and Evolution, Vol. 32 No. 11, pp. 825-834.

Pässilä, A., Owens, A., Kuusipalo-Määttä, P., Oikarinen, T. and Benmergui, R. (2017), "Beyond text: the co-creation of dramatised character and iStory", Journal of Work Applied Management, Vol. 9 No. 2, pp. 159-169.

Poole, S.E. (2017), "Re/searching for 'impact', Journal of Work Applied Management, Vol. 9 No. 2, pp. 147-158.

Robins, R.V. (2017), "Impact through coaching: does the use of models limit connectedness in coaching?", Journal of Work Applied Management, Vol. 9 No. 2, pp. 120-128.

Rossetti, L. and Wall, T. (2017), "The impact of story: measuring the impact of story for organisational change", Journal of Work Applied Management, Vol. 9 No. 2, pp. 170-184.

Rowe, L., Perrin, D. and Wall, T. (2016), "The chartered manager degree apprenticeship: trials and tribulations", Higher Education, Skills and Work-Based Learning, Vol. 6 No. 4, pp. 357-369, available at: https://doi.org/10.1108/HESWBL-05-2016-0034

Rowe, L., Moss, D., Moore, N. and Perrin, D. (2017), "The challenges of managing degree apprentices in the workplace: a manager's perspective", Journal of Work Applied Management, Vol. 9 No. 2, pp. 185-199.

Scott, D. (2017), “The ignorant manager: conceptualising impact with Rancière”, Journal of Work Applied Management, Vol. 9 No. 2, pp. 110-119.

Sparkes, A. (2007), "Embodiment, academics, and the audit culture: a story seeking consideration", Qualitative Research, Vol. 7 No. 4, pp. 521-550.

Sun, Q. and Kang, H. (2015), "Infusing work-based learning with Confucian principles: a comparative perspective", Higher Education, Skills and Work-Based Learning, Vol. 5 No. 4, pp. 323-338, available at: https://10.1108/HESWBL-04-2015-0019 
JWAM

9,2

94
Wall, T. (2016a), "Author response: provocative education: from the Dalai Lama's Cat ${ }^{\circledR}$ to Dismal Land®”, Studies in Philosophy and Education, Vol. 35 No. 6, pp. 649-653.

Wall, T. (2016b), "Žižekian ideas in critical reflection: the tricks and traps of mobilising radical management insight", Journal of Work-Applied Management, Vol. 8 No. 1, pp. 5-16.

Wall, T. (2016c), "Reviving the Ubuntu spirit in landscapes of practice: evidence from deep within the forest", Journal of Work-Applied Management, Vol. 8 No. 1, pp. 95-98.

Wall, T. (2017), "A manifesto for higher education, skills and work-based learning: through the lens of the manifesto for work", Higher Education, Skills and Work-Based Learning, Vol. 7 No. 3, pp. 304-314, available at: https://doi.org/10.1108/HESWBL-06-2017-0036

Wall, T. and Perrin, D. (2015), Slavoj Žižek: A Žižekian Gaze at Education, Springer, London.

Wall, T., Russell, J. and Moore, N. (2017), "Positive emotion in workplace impact: the case of a work-based learning project utilising appreciative inquiry", Journal of Work Applied Management, Vol. 9 No. 2, pp. 129-146.

Wall, T., Tran, L.T. and Soejatminah, S. (2017), "Inequalities and agencies in workplace learning experiences: international student perspectives", Vocations and Learning, Vol. 10 No. 2, pp. 141-156, doi: 10.1007/s12186-016-9167-2.

Wall, T., Bellamy, L., Evans, V. and Hopkins, S. (2017), "Revisiting impact in the context of workplace research: a review and possible directions", Journal of Work Applied Management, Vol. 9 No. 2 , pp. 95-109.

Wall, T., Hindley, A., Hunt, T., Peach, J., Preston, M., Hartley, C. and Fairbank, A. (2017), "Work-based learning as a catalyst for sustainability: a review and prospects", Higher Education, Skills and Work-Based Learning, Vol. 7 No. 2, pp. 211-224. 